\title{
Electricity Generation using Carboxymethyl Cellulose and Kitchen Waste as Substrate by Exiguobacterium sp SU-5 in Mediatorless Microbial Fuel Cell
}

\author{
Mittapalli Nagesh ${ }^{1}$, Senthilkumar P. ${ }^{2}$ (D) Jenifer Selvarani A. ${ }^{1}$ (D), \\ Raji P. ${ }^{1}$ (D), Kasirajan Kasipandian ${ }^{3}$, Paulraj Ponnaiah ${ }^{4}$, Iyappan Petchi ${ }^{4}$, \\ Antony V. Samrot ${ }^{4 *}$ (D) and Thirumurugan $\mathbf{R}^{5}$
}

\begin{abstract}
${ }^{1}$ Department of Biotechnology, Sathyabama Institute of Science and Technology, Jeppiar Nagar, Chennai - 600 119, Tamil Nadu, India. '2Department of Chemical Engineering, Sathyabama Institute of Science and Technology, Jeppiar Nagar, Chennai - 600 119, Tamil Nadu, India. ${ }^{3}$ Department of Electrical and Electronics Engineering, Faculty of Engineering and IT, MAHSA University, Jenjarom, Selangor - 42610, Malaysia. ${ }^{4}$ Department of Biomedical Sciences, Faculty of Medicine and Biomedical Sciences, MAHSA University, Jenjarom, Selangor - 42610, Malaysia. ${ }^{5}$ Department of Transfusion Medicine, JIPMER, Puducherry - 605 006, India.
\end{abstract}

\begin{abstract}
Microbial fuel cell (MFC) has become a great attraction amongst most researchers, where degradation of waste takes place simultaneously produces electricity. Using an efficient organism and a better proton exchange membrane gives out good electricity. In this study, Exiguobacterium sp SU-5 was isolated from soil and used for producing electricity against carboxy methyl cellulose (CMC) in Nafion membrane and Salt bridge fitted MFC, where both act as proton exchange membrane. The organism was found to produce more electricity in Nafion membrane fitted MFC. Later the organism was subjected to produce electricity against kitchen waste and the kitchen waste was also checked for BOD, COD and other water analysis before and after the treatment. The organism could produce more electricity in Nafion membrane fitted MFC and found to reduce chloride, fluoride and hardness of water.
\end{abstract}

Keywords: MFC; carboxy methyl cellulose; kitchen waste; electricity.

\footnotetext{
*Correspondence: antonysamrot@gmail.com

(Received: 21 October 2019; accepted: 10 December 2019)

Citation: Mittapalli Nagesh, Senthilkumar P., Jenifer Selvarani A., Raji P., Kasirajan Kasipandian, Paulraj Ponnaiah, Iyappan Petchi, Antony V. Samrot, Thirumurugan R, Electricity Generation using Carboxymethyl Cellulose and Kitchen Waste as Substrate by Exiguobacterium sp SU-5 in Mediatorless Microbial Fuel Cell, J Pure Appl Microbiol., 2019; 13(4):2151-2158. https://doi. org/10.22207/JPAM.13.4.27

(C) The Author(s) 2019. Open Access. This article is distributed under the terms of the Creative Commons Attribution 4.0 International License which permits unrestricted use, sharing, distribution, and reproduction in any medium, provided you give appropriate credit to the original author(s) and the source, provide a link to the Creative Commons license, and indicate if changes were made.
} 


\section{INTRODUCTION}

Microbial fuel cells (MFCs) have gained the attention of many researchers in recent years which is expected to become a promising means of organic waste management with the production of electrical energy. In MFC, the interaction between the microorganisms and the electrodes is brought by electrons transfer which further completes the electrical circuit to produce current ${ }^{1}$. MFCs are bioelectrochemical systems (BESs) which generates electricity through microbial metabolic degradation of the feed biomass. The efficacy of MFCs is dependent on its design and construction, recently researchers have studied the performance of MFCs with varied designs and unit components to increase its efficiency ${ }^{2}$. In a single chambered MFC, the microorganisms oxidize the organic matter in the anode chamber (Anaerobic conditions) and releases protons and electrons. These free electrons travel through the external circuit to reach the cathode which is directly exposed to air. While in a two chambered MFC, the proton transfer to the cathode occurs through ion-selective membrane. This prevents oxygen diffusion to anode and the anaerobic condition at anode chamber is well preserved. At the cathode (usually aerobic), the protons and electron acceptor (mainly oxygen) combine to produce water and the flow of electrons creates electrical output ${ }^{3}$. Besides these two common designs, several modifications have been incorporated in MFC design and structure ${ }^{2}$.

In MFCs, the material choice for substrate is considered as the most important biological factor affecting the electric output ${ }^{4}$. A great variety of substrates present in wastewater either in its pure compounds or as complex composition of organic matters can be used in MFCs for electricity production. Acetate is a simple carbon source and is widely used to promote the action of electroactive bacteria in MFC. It is also the end product of several metabolic pathways for higher order carbon sources which includes EntnerDoudoroff pathway for glucose metabolism ${ }^{5,6}$. Another commonly used substrate compound in MFCs is glucose. A maximum power density of 216 $\mathrm{W} / \mathrm{m}^{3}$ was recorded from a glucose fed-batch MFC using $100 \mathrm{mM}$ ferric cyanide as cathode oxidant ${ }^{7}$. Also, the substrate degradation by multispecies microbial community in MFCs show better energy production and substrate conversion. In a two-chambered MFCs with fed-batch control system using ferricyanide as the catholyte, the coculture of the electrochemically active Geobacter sulfurreducens and the cellulolytic fermenter Clostridium cellulolyticum achieved maximum power densities of $59.2 \mathrm{~mW} / \mathrm{m}^{2}$ and $143 \mathrm{~mW} / \mathrm{m}^{2}$ (anode area) from $1 \mathrm{~g} / \mathrm{L}$ carboxymethyl cellulose (CMC) and MN301 cellulose, respectively. Neither of the pure culture produced electricity from these substrates when used alone. The yield from CMC degradation by co-culturing increased from $42 \%$ to $64 \%$ compared to pure $C$.cellulolyticum culture. Likewise, rumen bacterial consortia were found to produce electricity with a power density of 55 $\mathrm{mW} / \mathrm{m}^{2}$ by consuming cellulose ${ }^{8}$. Huang and Logan experimented on paper recycling plant wastewater by adding $50 \mathrm{mM}$ phosphate buffer solution (PBS, $5.9 \mathrm{mS} / \mathrm{cm}$ ) which resulted with the power generation of $501 \pm 20 \mathrm{~mW} / \mathrm{m}^{2}$, with a coulombic efficiency of $16 \pm 2 \%$, with $73 \pm 1 \%$ removal of Soluble organic matter, $96 \pm 1 \%$ removal of cellulose over a 500-h batch cycle ${ }^{9}$. On evaluating the potential of various eco-systems through benthic fuel cells, it was attributed that water bodies with high organic matter could account for large power output. Mohan et $a^{10}$. also stated a similar report where the substrate concentration (carbon source) in the water body showed significant influence on bioelectricity production in benthic fuel cell since they act as potent electron donors. Thus, Water bodies with higher organic matter can also serve as better substrate for MFCs.

Therefore, it is clear that the choice of substrate and the acting microbial consortia reflects in the magnitude of current produced. Here, cellulose degrading organisms was isolated from soil sample and their efficiency of electricity production based on the cellulose degradation by single organism was studied in two different MFC models, one fitted with Nafion membrane and the other consists of a salt bridged system. $0.5 \%$ and $1 \%$ CMC (Carboxy Methyl Cellulose) was used as the substrate material for the isolated organism and the energy produced in each case, Nafion MFC and Salt bridge MFC was recorded. The electricity generated by the single organism on a single substrate was compared to the electricity produced by multiple consortia present in organic waste matter, like the kitchen waste. Kitchen 
waste acting as an enriched source of necessary metabolic components which is predominantly of plant-based products serve as a platform consisting of various active micro-organisms. MFC was set up using the kitchen waste where the microbial degradation by instinctive microbes were converted into energy production. Construction of MFC using the Kitchen waste can act as the best means of waste management with simultaneous production of electricity.

\section{MATERIALS AND METHODS}

Screening, Isolation and Identification of Microorganism

The microbial samples were collected from the garden soil of Sathyabama Institute of Science and Technology, Chennai. A total of 4 soil samples were taken in sterile containers. $1 \mathrm{~g}$ of each sample was inoculated into tube containing minimal media (Potassium dihydrogen phosphate (15g/L), Ammonium chloride (5g/L), Disodium hydrogen phosphate $(64 \mathrm{~g} / \mathrm{L})$, Sodium chloride $(2.5 \mathrm{~g} / \mathrm{L}), 1 \mathrm{M}$ Magnesium sulphate $(2 \mathrm{~mL} / \mathrm{L}), 1 \mathrm{M}$ Calcium chloride $(0.1 \mathrm{~mL} / \mathrm{L}))$ with $1 \%$ of carboxy methyl cellulose (CMC) and incubated at room temperature. After $24 \mathrm{~h}$ of incubation, the viscosity of the medium was compared with the control. After $48 \mathrm{~h}$ of incubation, the media was serially

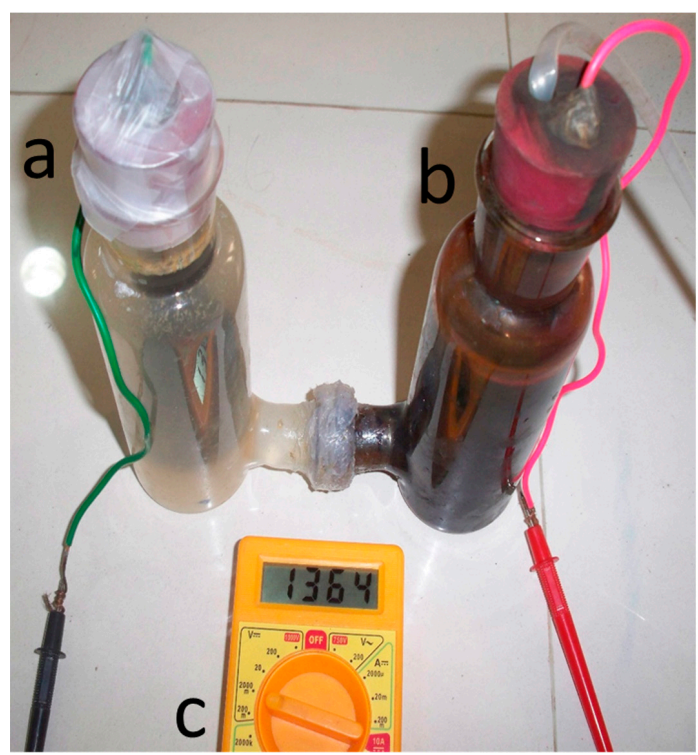

Fig. 1. Microbial fuel cell - double chambered fuel cell (with nafion membrane) a) anode chamber, b) cathode chamber c) multimeter. diluted and subject for pour plate using 1\% CMC containing minimal media agar. The colonies grown on cellulose medium was isolated and used for the study. Identification of the organism was done by biochemical tests and $16 \mathrm{~S}$ rRNA sequencing ${ }^{11}$.

\section{Collection of Kitchen Waste}

The Kitchen waste was collected from boy's mess, Sathyabama Institute of Science and Technology, Chennai. It was used as the source material for microbial degradation and thereby produce electricity.

\section{Construction of Microbial Fuel Cell \\ Pretreatment of Nafion Membrane}

The purchased Nafion membrane 117 ( $3^{*} 3 \mathrm{~cm}, 50$.pore size) was pretreated by heating at $80^{\circ} \mathrm{C}$ using $5 \%$ aqueous Hydrogen peroxide $\left(\mathrm{H}_{2} \mathrm{O}_{2}\right.$, $30 \%$ in $\mathrm{H}_{2} \mathrm{O}$ ) for $2 \mathrm{~h}$, rinsed 3-4 times in distilled water then placed in boiling water for $2 \mathrm{~h}$ and finally washed in deionized water. Finally fixed to the MFC and checked for leakage ${ }^{12}$.

\section{Pretreatment of Electrode}

The graphite electrodes were soaked in IPA (Iso propyl Alcohol) for 30 mins and washed with $1 \mathrm{~N} \mathrm{HCl}$ and $1 \mathrm{~N} \mathrm{NaOH}$ to eliminate the fouling of metal ${ }^{13}$.

\section{Cathode Chamber}

$10 \mathrm{mM}$ of Potassium permanganate (KMnO4) was aerated with mechanical pumps, which is used as the catholyte ${ }^{14}$.

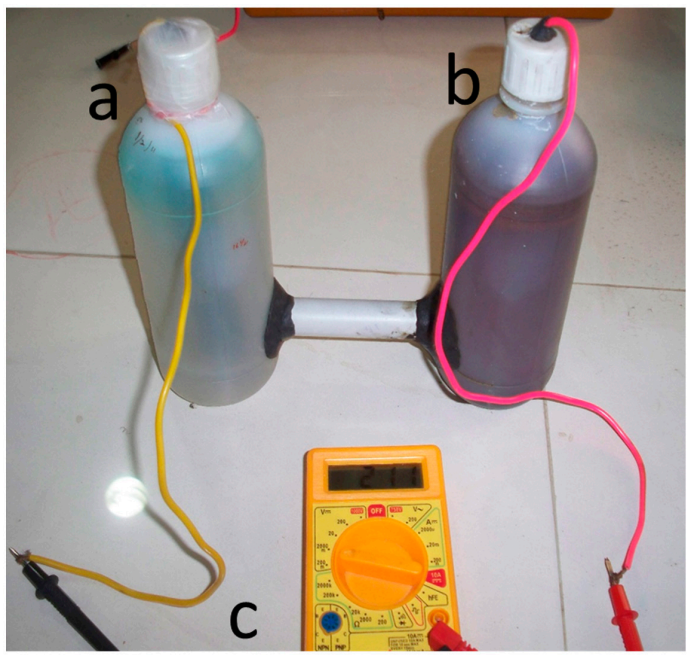

Fig. 2. Microbial fuel cell - double chambered fuel cell (with salt bridge) a) anode chamber, b) cathode chamber c) multimeter. 


\section{Construction of Microbial Fuel Cell and Electricity generation in MFC}

The H-shaped microbial fuel cell comprises of an aerated cathode chamber and an anaerobic anode ${ }^{15}$. Both the chambers were connected using a clamp which is fitted with proton exchange membrane-117 (Nafion ${ }^{\mathrm{TM}}$ DuPont co) Fig. 1. The carbon electrode of size $69.5325 \mathrm{~cm}^{2}$ were connected by means of an insulated copper wire to complete the circuit. Anode chamber was having the capacity of $375 \mathrm{~mL}$. The anaerobic condition at the anode was configured by sealing with PTFE (Poly tetra fluoro ethylene) tapes and aeration was provided to the cathode using the air pump Fig. 1.

Another MFC was constructed with similar components such as anaerobic anode chamber and an aerobic cathode chamber Fig. 2 but the connection between the two chambers was brought with salt bridge as the proton exchange of length $11.5 \mathrm{~cm}^{16}$. The salt bridged MFC were constructed using available plastic bottles of capacity $500 \mathrm{~mL}$, which were connected using salt bridge made of PVC pipe filled with saturated $\mathrm{NaCl}$ in $2 \%$ agar (boiled and poured). Graphite electrodes of size $69.5325 \mathrm{~cm}^{2}$ was used in both the chambers. Anaerobic condition was maintained in the anode chamber whereas aerobic condition was maintained in cathode chamber using aerator pumps. Both the setups were kept in room temperature $28 \pm 2^{\circ} \mathrm{C}$.

The anode compartment of constructed units were loaded with $375 \mathrm{ml}$ for Nafion membrane chamber and $500 \mathrm{ml}$ for the salt bridge setup with either $0.5 \%$ or $1 \% \mathrm{CMC}$ in minimal media (Potassium dihydrogen phosphate (15g/L), Ammonium chloride $(5 \mathrm{~g} / \mathrm{L})$, Disodium hydrogen phosphate $(64 \mathrm{~g} / \mathrm{L})$, Sodium chloride $(2.5 \mathrm{~g} / \mathrm{L}), 1 \mathrm{M}$ Magnesium sulphate ( $2 \mathrm{~mL} / \mathrm{L}), 1 \mathrm{M}$ Calcium chloride $(0.1 \mathrm{~mL} / \mathrm{L}))$ and inoculated with the isolated

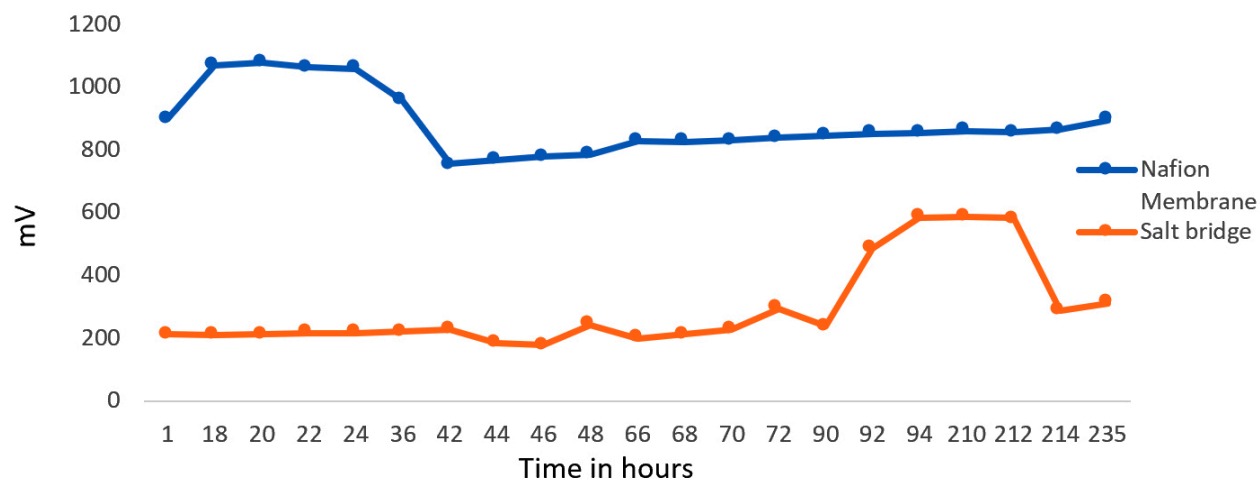

Fig. 3. Electricity generation by Exiguobacterium sp SU-5 in $0.5 \%$ carboxy methyl cellulose containing medium.

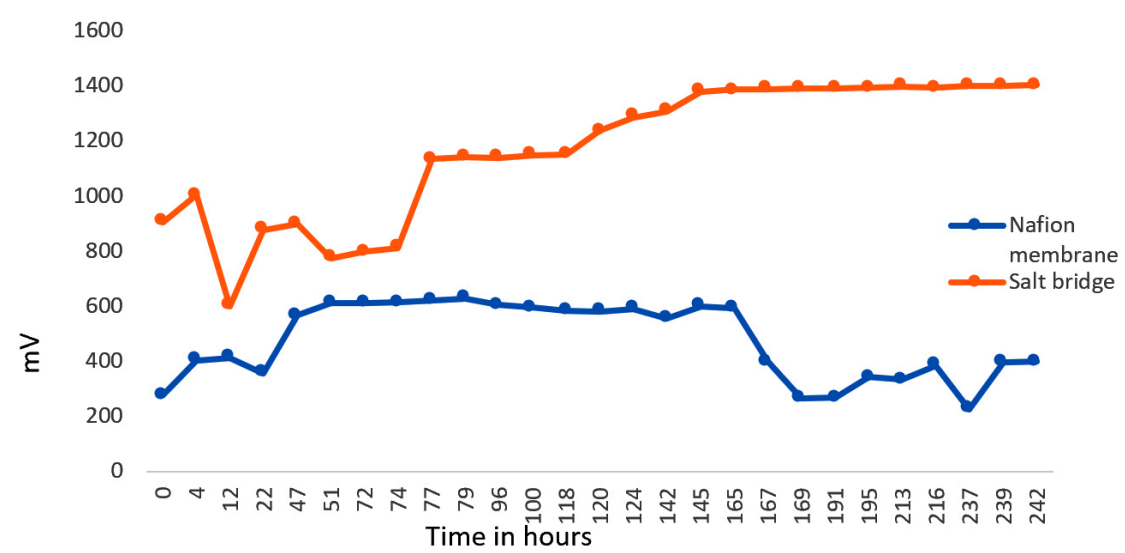

Fig. 4. Electricity generation by Exiguobacterium sp SU-5 in $1 \%$ carboxy methyl cellulose containing medium . 
bacterial culture ( $1 \%$ inoculum). The microbial activity in the anode chamber was preserved at anaerobic condition throughout the study. Using a digital multimeter, the current flow and the potential difference between the electrodes in MFC were measured at regular time interval for 10 to 11 days only. Later, the source material of anode chamber was replaced with the kitchen waste collected from the Boy's mess, Sathyabama Institute of Science and Technology. Prior to adding to the anode chamber, kitchen waste was ground to semisolid state, made upto $200 \mathrm{~mL}$ and autoclaved $^{17}$.

\section{Monitoring the Readings}

The current/voltage generated by the constructed MFC's were measured using a rheostat by constant current and constant voltage method.

\section{Analysis of Kitchen Waste}

Kitchen wastewater was subjected for following analysis before and after (10 days) subjugating to MFC: protein content, carbohydrate content, BOD / COD analysis ${ }^{18,19}$. Estimation of Chloride, Fluoride, Nitrate, Iron Residual Free Chlorine Test and Hardness of Water was analysed using water testing kit (HiMedia, WT023)

\section{RESULTS}

\section{Screening, Isolation and Identification of Isolated} Microorganism

The sample was found to liquify the cellulose media and was subjected for isolation and identification. One organism was isolated and identified on the basis of 16SrRNA sequencing as Exiguobacterium SU-5 (GENBANK accession number GU395989).

\section{Generation of Electricity from Microbial Fuel Cell} MFC with $0.5 \%$ and $1 \%$ CMC Media

The constructed units were loaded with $0.5 \%$ and $1 \% \mathrm{CMC}$ media inoculated with the isolated colony, Exiguobacterium sp SU-5. From the graph Fig. 3 it is observed that when 0.5\% CMC media was used, the electricity production was greater in Nafion membrane fitted Microbial fuel cell compared to salt bridged microbial fuel cell. Nafion membrane fitted Microbial fuel cell showed an upsurge of electricity production during the initial hours of incubation and reached a maximum production of $1067 \mathrm{mV}$ current at the $18^{\text {th }}$ hour. On further incubation, the electricity generation dropped gradually reaching a constant production of $800 \mathrm{mV}$ from the $44^{\text {th }} \mathrm{h}$. The prolonged incubation does not seem to have influenced the power generation where the minimum production

Table 1. Analysis of kitchen waste treatment in MFC

\begin{tabular}{lccc}
\hline S.No & Parameter & \multicolumn{2}{c}{$\begin{array}{c}\text { Concentration } \\
(\mathrm{mg} / \mathrm{L})\end{array}$} \\
& & Before & After \\
& & & \\
\hline 1. & Protein Estimation & 137.5 & 112.5 \\
2. & Reducing sugar & 124 & 23 \\
3. & COD & 180 & 80 \\
4. & BOD & 19.5 & 6.79 \\
5. & Chloride Test & 150 & 160 \\
6. & Flouride Test & 2.0 & 1.5 \\
7. & Nitrate Test & 0.0 & 10.0 \\
8. & Iron Test & 0.5 & 0.3 \\
9. & RF Chlorine Test & 0.0 & 0.0 \\
10. & Hardness Of Water & 1975 & 1925 \\
& & & \\
\hline
\end{tabular}

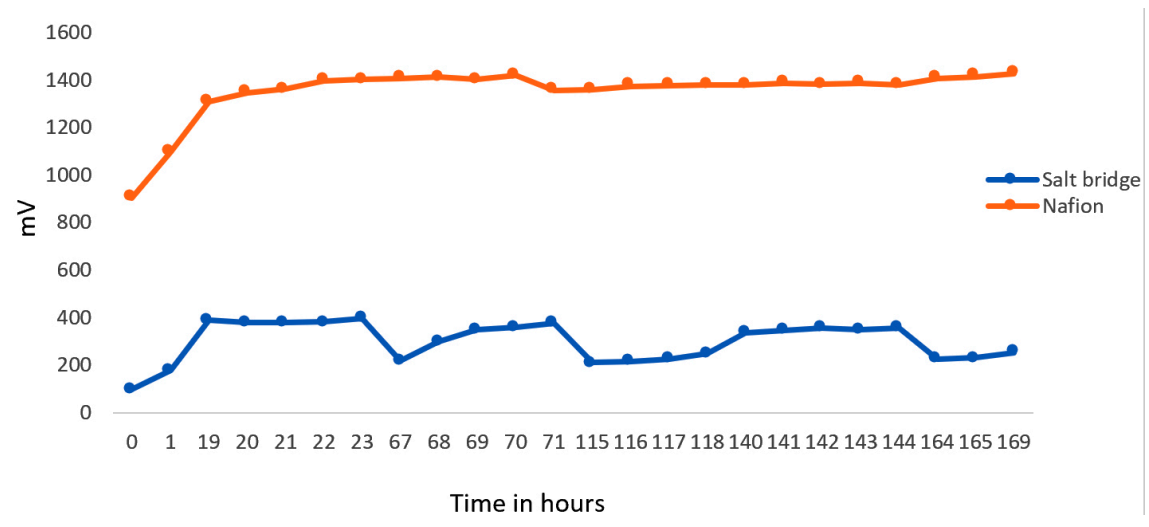

Fig. 5. Electricity generation utilizing kitchen waste by Exiguobacterium sp SU-5. 
of $800 \mathrm{mV}$ was maintained on incubation beyond $44^{\text {th }} \mathrm{h}$. In salt bridge system, the initial hours of incubation developed a constant voltage of $200 \mathrm{mV}$ till $92^{\text {nd }} \mathrm{h}$ and an increase in current, producing $580 \mathrm{mV}$ which is relatively less compared to Nafion MFC. This was concluded with the fact that the efficiency of proton transfer through salt bridge from anodic chamber to cathodic chamber was minimal than the Nafion membrane. In 1\% CMC Media MFC, Exiguobacterium sp SU-5 generated 1350 - $1400 \mathrm{mV}$ in Nafion fitted MFC unit from the $140^{\text {th }} \mathrm{h}$ and continued till the $250^{\text {th }} \mathrm{h}$ whereas only around $500 \mathrm{mV}$ of electricity was produced in salt bridge system from $48^{\text {th }}$ hour and then it got reduced at $168^{\text {th }}$ hour and did not get increased (Fig. 4). Again, Nafion MFC was found to be the best system for producing electricity while degrading cellulose.

Kitchen waste collected from boy's mess, Sathyabama Institute of Science and Technology was found to produce appreciable quantity of electricity than ever reported i.e it constantly produced electricity of $1400 \mathrm{mV}$ upto 170 hours Fig.5. Again, Salt bridge system failed to produce more electricity as it produced in Nafion MFC. It was reported that the salt concentration used in the salt bridge can affect the channelling of protons. An increased molar concentration can account for high internal resistance and thereby produce lower current ${ }^{20}$. To be more analogous with the above result, Shahi et al has also reported the same using wastewater as a substrate. He performed a comparative study with Nafion and agar salt bridged MFCs where the power output from MFCs constructed with agar salt bridge (0.145 V) was much lower to Naifion membrane fitted MFC (0.504 V). Therefore, it clearly explains that the membrane offers less resistance to proton channelling when compared with salt bridge ${ }^{21}$. In a mediator less microbial fuel cell, electron transfer between a microbe and an electrode takes place through the active centre of the released enzymes which directly get allied to the electrode thus facilitates electron transfer. In such a case, the rate of electron transfer can be very low if the active site of the involving enzymes is insulated by random proteins in the environment and the isolation of the enzyme from the electrode surface by its relative burial into the bacterial membrane. Whereas in exoelectrogens species, the redox enzymes are present on the outer surface of the microbial membrane which participate in electron transport. Electron transfer can also be active through pilli of $2-3 \mathrm{~mm}$ long which is also referred as biological nanowires ${ }^{22}$.

\section{Analysis of kitchen waste}

The protein content was assessed from kitchen waste by Lowry's method ${ }^{23,24}$. The protein quantity reduced from $137.5 \mathrm{mg} / \mathrm{l}$ to $112.5 \mathrm{mg} / \mathrm{l}$ after treatment. The reducing sugar were quantified by DNS method where an initial concentration of $124 \mathrm{mg} / \mathrm{I}$ were utilized to reach a final concentration of $23 \mathrm{mg} / \mathrm{l}$ after treatment (Table 1). It is evident that the organism had a significant effect on the other parameters too. It was found to reduce the hardness of water, chloride content and fluoride content (Table 1). Chitosan and wastewater had been used for production of bioelectricity in $\mathrm{MFC}^{25,26}$.

\section{CONCLUSION}

Exiguobacterium sp SU-5 was collected from the garden soil and utilized for electricity generation from Carboxymethyl cellulose and kitchen waste in Nafion membrane and Salt bridge fitted mediatorless MFC. More electricity was found to be produced in Nafion membrane fitted MFC.

\section{ACKNOWLEDGEMENT}

None.

\section{CONFLICT OF INTEREST}

The authors declare that there is no conflict of interest.

\section{AUTHOR'S CONTRIBUTION}

All the authors involved in idea creation and made intellectual contribution to the work. All the authors involved in manuscript preparation.

\section{FUNDING} None.

\section{DATA AVAILABILITY}

Not applicable. 


\section{ETHICS STATEMENT}

No animals or humans are used in this study. Hence, the work does not require ethical clearance.

\section{REFERENCES}

1. Rabaey, K., Rodriguez, J., Blackall, L.L., Keller, J., Gross, P., Batstone, D., Verstraete, W., Nealson, K.H. Microbial ecology meets electrochemistry: electricity driven and driving communities. ISME J., 2007; 1: 9-18. https:// doi.org/10.1038/ismej.2007.4

2. Du, Z., Li, H., Gu, T. A state of the art review on microbial fuel cells: a promising technology for wastewater treatment and bioenergy. Biotech. Adv., 2007; 25: 464-482. https://doi.org/10.1016/j. biotechadv.2007.05.004

3. Li, Z., Zhang, X., Zeng, Y., Lei, L. Electricity production by an overflow-type wetted microbial fuel cell. Biores. Technol., 2009; 100: 2551-2555. https://doi. org/10.1016/j.biortech.2008.12.018

4. Liu Z, Liu J, Zhang S, Su Z. Study of operational performance and electrical response on mediator-less microbial fuel cells fed with carbon- and protein-rich substrates. Biochem. Eng. J., 2009; 45; 185-191. https://doi.org/10.1016/j.bej.2009.03.011

5. Bond, D.R., Lovely, D.R. Electricity Production by Geobacter sulfurreducens Attached to Electrodes. Applied and Environmental Microbiology, 2003; 69: 1548-1555. https://doi.org/10.1128/AEM.69.3.15481555.2003

6. Biffinger, J.C., Pietron, J., Bretschger, O., Nadeau, L.J., Johnson, G.R., Williams, C.C., Nealson, K.H., Ringeisen, B.R. The influence of acidity on microbial fuel cells containing Shewanella oneidensis. Biosens Bioelectron, 2008; 24: 906-11. https://doi.org/10.1016/j. bios.2008.07.034

7. Rabaey, K., Lissens, G., Siciliano, S.D., Verstraete, W. A microbial fuel cell capable of converting glucose to electricity at high rate and efficiency. Biotechnology letters, 2003; 25: 1531-1535. https:// doi.org/10.1023/A:1025484009367

8. Rismani-Yazdi, H., Christy, A.D., Dehority, B.A., Morrison, M., Yu, Z., Tuovinen, O.H. Electricity generation from cellulose by rumen microorganisms in microbial fuel cells. Biotechnol Bioeng., 2007; 97: 1398-1408. https://doi.org/10.1002/bit.21366

9. Huang, L., Logan, B.E. Electricity generation and treatment of paper recycling wastewater using a microbial fuel cell. Applied Microbiology and Biotechnology, 2008; 80:. 349-355. https://doi. org/10.1007/s00253-008-1546-7

10. Mohan, S.V., Srikanth, S., Raghuvulu, S.V., Mohanakrishna, G., Kumar, A.K., Sarma, P.N. Evaluation of the potential of various aquatic eco-systems in harnessing bioelectricity through benthic fuel cell: effect of electrode assembly and water characteristics. Biores. Technol., 2009; 100: 2240-2246. https://doi. org/10.1016/j.biortech.2008.10.020
11. Pitcher, D.G., Saunders, N.A., Owen, R.J. Rapid extraction of bacterial genomic DNA with guanidium thiocyanate. Letters in Applied Microbiology, 1989; 8: 151-156. https://doi.org/10.1111/j.1472-765X.1989. tb00262.x

12. Choi, J.S., Sohn, J.Y., Shin J. A Comparative Study on EB-Radiation Deterioration of Nafion Membrane in Water and Isopropanol Solvents. Energies, 2015; 8: 5370-5380. https://doi.org/10.3390/en8065370

13. Wang, H., Feng, Q., Tang, X., Liu, K. Preparation of highpurity graphite from a fine microcrystalline graphite concentrate: Effect of alkali roasting pre-treatment and acid leaching process. Separation Science and Technology, 2016; 51: 2465-2472. https://doi.org/1 0.1080/01496395.2016.1206933

14. Pandit, S., Sengupta, A., Kale, S., Das, D. Performance of electron acceptors in catholyte of a two-chambered microbial fuel cell using anion exchange membrane. Bioresour Technol., 2011; 102: 2736-2744. https://doi. org/10.1016/j.biortech.2010.11.038

15. Flimban, S., Oh, S.E., Joo, J.H., Hussein, K.A. Characterization and Identification of Cellulosedegrading Bacteria Isolated from a Microbial Fuel Cell Reactor. Biotechnology and Bioprocess Engineering, 2019; 24: 1-10. https://doi.org/10.1007/s12257-0190089-3

16. Min, B., Cheng, S., Logan, B.E. Electricity generation using membrane and salt bridge microbial fuel cells. Water Research, 2005; 39: 1675-1686. https://doi. org/10.1016/j.watres.2005.02.002

17. Garba NA, Sa'adu L, Balarabe, MD. An Overview of the Substrates used in Microbial Fuel Cells. Greener Journal of Biochemistry and Biotechnology, 2017; 4: 007-026. https://doi.org/10.15580/GJBB.2017.2.051517061

18. Carpenter JH. The Chesapeake Bay Institute. Technique for the Winkler oxygen method. Limnol. Oceanogr., 1965; 10: 141-143. https://doi.org/10.4319/ lo.1965.10.1.0141

19. AWWA, WEF, APHA, Standard Methods for the Examination of Water and Wastewater (Methods: 5220 C. Closed Reflux Titrimetric Method), 1998.

20. Sevda, S., Sreekrishnan, T.R. Effect of salt concentration and mediators in salt bridge microbial fuel cell for electricity generation from synthetic wastewater. J. Environ. Sci. Health A Tox Hazard Subst. Environ. Eng., 2012; 47(6): 878-86.https://doi.org/10.1080/109345 29.2012.665004

21. Shahi, A., Rai, B.N., Singh, R.S.A comparative study of a bio fuel cell with two different proton exchange membrane for the production of electricity from waste water. Resource-Efficient Technologies, 2017; 3: 78-81. https://doi.org/10.1016/j.reffit.2017.01.006

22. Tender, L.M., Reimers, C.E., Stecher, H.A., Holmes, D.E., Bond, D.R., Lowy, D.A., Pilobello, K., Fertig, S.J., Lovley, D.R. Harnessing microbially generated power on the seafloor. Nature Biotechnology, 2002; 20(8): 821-825. https://doi.org/10.1038/nbt716

23. Lowry, O.H., Rosebrough, N.J., Fair, A.L., Randall, R.J. Protein Measurement with the Folin Phenol Reagent. J. Biol. Chem., 1951; 193: 265-275. 
24. Zaher, U., Buffiere, P., Steyer, J.P., Chen, S. A Procedure to Estimate Proximate Analysis of Mixed Organic Wastes. Water Environment Research, 2009; 81: 407415. https://doi.org/10.2175/106143008X370548

25. Kumar, G.G., Kirubaharan, C.J., Yoo, D.J., Kim, A.E. Graphene/poly(3,4-ethylenedioxythiophene)/ $\mathrm{Fe}_{3} \mathrm{O}_{4}$ nanocomposite - An efficient oxygen reduction catalyst for the continuous electricity production from wastewater treatment microbial fuel cells. International Journal of Hydrogen Energy, 2016;
41(30): 13208-13219. https://doi.org/10.1016/j. ijhydene.2016.05.099

26. Karthikeyan, C., Sathishkumar, Y., Soo, L.Y., Rhan, K.A., Jin, D.Y., Gnana, K.G. The Influence of Chitosan Substrate and Its Nanometric Form Toward the Green Power Generation in Sediment Microbial Fuel Cell. Journal of Nanoscience and Nanotechnology, 2017; 17(1): 558-563. https://doi.org/10.1166/ jnn.2017.12090 